\section{EXPLORING THE MEDIASCAPE FROM THE EPISTEMOLOGIES OF THE SOUTH}

\author{
Alexandre de Sousa Carvalho \\ University of Coimbra (Portugal) \\ ORCID: 0000-0002-9096-393X \\ asousacarvalho@fe.uc.pt
}

\section{EXPLORANDO EL MEDIASCAPE DESDE LAS EPISTEMOLOGIAS DEL SUR}

\author{
Sofia José Santos \\ University of Coimbra (Portugal) \\ ORCID: 0000-0001-9300-7452 \\ sjs@ces.uc.pt
}

\author{
Carlota Houart \\ University of Coimbra (Portugal) \\ ORCID: 0000-0002-7428-6852 \\ carlotahouart@ces.uc.pt
}

Para citar este artículo:

De Sousa Carvalho, A., Santos, S.J. \& Houart, C. (2020). Exploring the Mediascape from the Epistemologies of the South. Commons. Revista de Comunicación y Ciudadanía Digital, 9(2), 211-237. http://doi.org/10.25267/COMMONS.2020.v9.i2.07

Fecha de recepción: 20/02/2019. Fecha de aceptación: 27/04/2020

\begin{abstract}
Dominant literature on media and communication studies has insistently equated mediascape and high technology media as interchangeable concepts and realities instead of high technological media as part of a broader and more dynamic media pallet. By subscribing to this "technology-driven Darwinism", we argue that existing dominant literature explicitly and implicitly excludes forms of mass communication that go beyond the media in its Western liberal form and procedures and, consequently, other voices, knowledge and messages. This article analyses the modern conception of media by exploring the "abyssal exclusions" (Santos, 2007) it creates. To illustrate this further, we have selected the top five 2018 SCOPUS-indexed journals, from which we gathered a sample of 116 research articles that were published between 2016-2018, to shed light on some of the most recent research trends in media studies. The definition of media used by the articles contained in our sample shows that there is a technological and modernity-driven spectrum which is fundamental in defining what is and what progressively is no longer labelled, and hence considered, media. This understanding of the media fails to include forms of mass communication that go beyond the media in its western liberal form and, consequently, exclude subaltern voices, knowledges and messages.
\end{abstract}

\section{Keywords}

Media, voice, epistemologies of the south, communication grammars, ecologies of communication

\section{Resumen}

La literatura dominante sobre los medios y los estudios de comunicación ha igualado insistentemente los medios de comunicación y los medios de alta tecnología como conceptos y realidades intercambiables en lugar de los medios de alta tecnología como parte de una paleta de medios de comunicación que és más amplia y dinámica. Al suscribirse a este "darwinismo tecnologico", argumentamos que la literatura dominante existente excluye explícita e implícitamente las formas de comunicación masiva que van más allá de los medios en su forma $y$ procedimientos liberales occidentales $y$, en consecuencia, excluye otras voces, conocimientos y mensajes. Este artículo analiza la concepción moderna de los medios de comunicación, explorando las "exclusiones abisales" (Santos, 2007) que crea. Para ilustrar esto más a fondo, hemos seleccionado las cinco principales revistas de 2018 indexadas en SCOPUS, de las cuales reunimos una muestra de 116 artículos de investigación que se publicaron entre 2016-2018, para arrojar luz sobre algunas de las tendencias más recientes en la investigación de estudios de medios. La definición de los medios utilizados por los artículos contenidos en nuestra muestra demuestra que existe un espectro tecnológico y de modernidad que es fundamental para definir qué es y qué progresivamente deja de ser etiquetado y, por lo tanto, considerado como medio. Esta comprensión de los medios no incluye formas de comunicación de masas que vayan más allá de los medios en su forma liberal occidental y, en consecuencia, excluyen voces, conocimientos y mensajes subalternizados.

\section{Palabras clave}

Media, voz, epistemologías del sur, gramáticas de comunicación, ecologías de comunicación 


\section{Introduction}

When creating a definition, one's expressing the essential nature of something, codifying the reality the concept intends to synthesize. Once brought to consensus (i.e., general concord crosscutting academia, political institutions and even common sense) and mainstreamed (usually employing science and/or other forms of knowledge or social practices) in society, a definition enables one and all to have a common understanding of a word or subject, allowing a more functionally efficient framework when discussing, reasoning, talking, deciding or reading about an issue. Concepts, however, have weight and are not aseptic - i.e., the act of defining a concept does not occur in a vacuum: it is socially, politically and culturally grounded and, hence, it is influenced by, if not a result of, existing power (co)relations-. As Foucault (1980) argues, their significance holds specific references and gives meaning to speech; they guide and set the boundaries of both the common understanding as well as of those who can be recognised or ignored, those who can participate and those who cannot take part. Realities, subjects, objects or elements included and excluded in a specific definition face different possibilities. When reasoning on communication within today's hegemonic context of western modernity, the conceptual question of what is included and excluded when defining media is, hence, a particularly key and yet overlooked aspect.

When thinking about the media, one's mind easily tends to wander through ideas and notions of technology, airwaves, satellite, automaticity, immediacy, which themselves entail a logic of rationality and scientific background. Indeed, existing literature on media and communications studies have equated mediascape ${ }^{1}$ - the cumulative spheres and tools of communication within the public discourse that reaches and influences people widely - and the high technological media to be perceived as interchangeable concepts and realities, instead of high technological media as part of a wider mediascape pallet and dynamic (Araújo \& Santos, 2017).

1. Mediascape is understood in this article as communications media as a whole. 
This happens because the evolution of what is commonly understood as the media, i.e. the means of communication that reaches and influences people widely, goes on par with the evolution of the modern society and has, hence, been defined through a modern ${ }^{2}$ and high technologically-driven approach. However, notwithstanding this trend, there are many other non-technological or technologically obsolete media.

By frequently overlapping high-tech media with media in terms of category, existing literature conflates both terms into a single concept. Consequently, when perceiving and reasoning on what is the media one can easily fall into what we label as an "optical illusion" trap, where the notion of the media, despite perceived as a whole, is filled mostly by one of its parts - the high-technology part assumes the neuralgic whole of the mediascape, rendering all other media expressions and channels peripheral, invisible or dismissed as folk, "unconsequential" (Ansy-Kyeremeh, 2005: 1) or less important-. This is hegemonically repeated and mainstreamed into dominant science and policy initiatives (Foucault, 1995 [1975]; Gramsci, 1971), as the bulk of Media Studies literature illustrates.

By being conceptually defined and constructed as such, this optical illusion that constitutes the dominant conception of the media, we argue, fuels a hierarchical relation among different media, denying and validating selectively specific knowledge, grammars and ecologies of communication, technologies as well as voices. Tipping the balance by validating and projecting some in detriment of others' neglect or exclusion, this process affects and has consequences in power relations and, subsequently, in society's inclusion, maintenance and transformation -both at a local, national and international level-.

This article analyses the modern conception of media created and hegemonically enforced by the current liberal hegemony, which is expressed both in terms of knowledge creation and policy initiatives. Stemming from a post-colonial perspective focused on the Epistemologies of the South and taking into account critical media studies on "voice" (Couldry, 2010; Tacchi 2011, 2012), this article intends to contribute to an ongoing debate on de-westernising (Wilson, 1987;

2. Here modern is perceived as deriving from modernity as a social, political, economic and cultural project. 
Nyamnjoh, 2011; Shome, 2016; Kumar \& Paraweswaran, 2018) both media theory and media as practice. For that purpose, it is structured into four parts: the first presents the theoretical and analytical framework from which this article departs; the second one applies the post-colonial theoretical framework to the media realm; the third offers a quantitative and qualitative illustrative analysis of the 2018 top 5 media and communications journals indexed to SCOPUS; and the fourth and last part discusses the implications of this choice of definition of the media.

\section{2. "The West" and "the Rest": the "indolent reason" and the "abyssal line"}

"The West" and "the Rest" is a systematisation drawn by Stuart Hall (2007) of the prevailing universalised western discourse which highlights the European uniqueness to which the rest of the world is inferiorly compared to. The construction of the "West" was itself created as an antipode to the Rest, particularly enhanced with the European expansion overseas and the beginning of modern times, mostly the Enlightenment Era, when the latest DNA of the West - understood not as a geographic category, but rather as a social, political, economic and cultural one- was crafted. The West and the Rest was built upon an essentialist systematisation of the world which divided it into two hierarchical poles by means of "crude and simple distinctions" as well as the "construct[ion of] an oversimplified conception of difference" (Hall, 2007: 189). On the one hand, the "West" corresponded to modern, rational, progressive; while on the other hand, there is the Rest: inferior, underachieved, and irrational -in short, "westless"- The West and the Rest dichotomy renders unintelligible the wide differences among West's peoples and the Rest's peoples, erroneously presenting them as two homogenous wholes. "The West" is presented as an ideal model that supplies the standards of evaluation according to which "the Rest" societies are graded and ranked (Hall, 2007). Once produced as a concept, "the West" "became productive in its turn" (Ibid: 187), producing knowledge on people, subjects and 
realities, and effectively became "both the organizing factor in a system of global power relations and the organizing concept or term in a whole way of thinking and speaking" (Ibidem).

Being an artificial but hegemonic construction, this framework persists both as an implicit and explicit reference to interpret the world, well beyond the formal end of political colonialism. Based on this hegemonic world interpretation system lies, according to Sousa Santos (2007), the "indolent reason" in its metonymic expression: it labels, by omission or explicitly, "the West" as developed and, hence, all "the Rest" as underdeveloped, neglecting its specificities and a myriad of other characteristics. Within its hegemonic context, and as the comprehension of the world widely exceeds the western comprehension of the world (Santos, 2007), the indolent reason produces what Santos coins as an "abyssal line" (Santos, 2007) which divides the world into two realms - the universe on one side of the line which fits the visible western modernity framework and societies (e.g. rational, modern, technological, scientific); and the universe across the line (e.g. irrational, exotic, pre-scientific, superstitious) which is perceived and categorized not for what it is per se, but in relative terms, i.e., for how distant it is from the visible, assumed universal, and modern standard model-. This creates a self-fulfilling duality, where the modern always exists in opposition to the pre-modern and the irrational can only be categorized or labelled, as such, in contrast to the rational.

Based on these artificial, biased and oversimplified symmetries, the abyssal thinking renders invisible or subalterns "Westless" realities, thus wasting experiences and knowledges (Santos, 2007). With this in mind, Santos (Ibidem) argues that only through a "post-abyssal thinking" can an "ecology of knowledges" emerge and open up a horizontal dialogue among different knowledges and different grammars of perceiving and organising societies. The "post-abyssal thinking" (Ibidem) is thus based upon the acknowledgement of a plurality of forms of knowledges that includes, but is not limited to, the western experience, therefore renouncing to any general epistemology since all knowledges are incomplete. 


\section{Voice matters: by excluding media, voices are excluded}

Voice holds power - a power that people can use to explicitly or implicitly describe the world within which they act (Couldry, 2010: 7)—. This possibility to describe also carries the potential to shape discourses and perceptions of a given reality, consequently preserving or transforming individuals, groups, communities and societies. The power of voice therefore includes the possibility to express how a subject perceives the surrounding world, and to explore agendas that intend either to keep that world as it is, or to transform it in some way. To have a voice is to be capable of defining problems, of debating, of setting agendas. People's act of talking and speaking allows for denouncement, contestation, support, consensus making, self-positioning and identity reinvention. Having a voice and being able to use it as a vehicle for expression - of feelings, thoughts, ideas, beliefs - is an unquestionable value.

However, as Couldry (2010) argues, having a voice is not enough. Voice has to be socially and politically consequential; that is, it must be socially and politically grounded and produce an echo in society. First, then, it requires recognition: "Equal opportunity for participation in practical discourse requires (...) [equal] degree of social recognition and corresponding individual self-respect" (Honneth, 1985: 192 apud Anderson, 1995: 181). To make sense of the power of voice, Nick Couldry (2010) proposes two basic formulations of the term: "voice as a value" and "voice as a process". There is an essential difference between the two, because while "voice as a process" simply identifies human capacity to give an account of oneself and one's place in the world, "voice as a value" is the act of valuing voice: recognising that voice matters. Valuing voice involves "discriminating in favour of ways of organising human life and resources that, through their choices, put the value of voice into practice, by respecting the multiple interlinked processes of voice and sustaining them, not undermining or denying them" (Couldry, 2010: 2). To support the idea of "voice as a value" is to recognise the fact that people are generally capable of perceiving and describing themselves and the world around them, and to put in motion subsequent political consequences. Using one's voice must be made not only to express one's personal views, but also to recognise the user of the voice and to get consequential results in political debates (Appadurai, 2004 ) and in the construction of societies. Such a recognition allows for one's 
accounts, identities, needs and experiences to echo in society. To make voice matter is to stand for both "voice as a process" and "voice as a value" (Couldry, 2010), "prioritising effective listening" (Tacchi, 2011) and acknowledging, respecting and embracing all forms of knowledge that voices express, keeping in mind that all knowledges are incomplete and therefore demand a horizontal exchange in order to be challenged and improved (Santos, 2007).

\section{Media and the mediascape: Unveiling the modern optical illusion}

As a broad concept, media intends to synthesize the process of different channels of communication broadcasting and/or acting in the public space, considered individually or as a whole, which transmit information, entertainment, propaganda and/or advertisement to a wide range of receptors.

Although it was only in the 1920s (Briggs \& Burke, 2009) and in the Global North that the word "media" emerged, media as practice (i.e., the communicative and discursive processes of transmission of a message to a large number of receivers) dates back to the conception of cave paintings and other pictographic and spoken communication tools (Briggs \& Burke, 2009). Likewise, examples of media practice can also be found throughout distinct geographies ${ }^{3}$. However, the evolution of what is the common conception of the media has been in line with the western modernity and its meta-narrative of progress (e.g. Santos et al., 2016; Araújo \& Santos, 2017), being all other communication grammars or ecologies of communication dismissed as traditional, antiquated, exotic, folk or alternative. Consequently, the knowledges and the accounts that the voices using these media express are also rendered inferior, pre-modern and susceptible to being legitimately overpassed or positively upgraded.

As concepts express the essential nature of the reality they intend to codify, they refer and give meaning to speech; they guide and set the boundaries of a specific phenomenon within the public debate and public policies. Emphasizing how discursive formations shape actions and codes of conduct, two examples might be given. The recent case of the debate among different media and politicians on

3. Cf. Cohen \& Glover (2014) and Ansu-Kyeremeh (2005). 
whether to name refugees or migrants to those people arriving in Europe after fleeing Syria's war is elucidative of the importance of words used, of how we label specific subjects, objects, events, topics or relations. Likewise, when the USA declared the battle waged against terrorism as a "war on terror":

The Bush administration determined that its "war on terror" was neither an international nor a non-international armed conflict because Al-Qaeda was not a State party to the Geneva Conventions and the conflict went beyond the territory of one State. Furthermore, it held that its enemies in the conflict were neither combatants nor civilians but unlawful combatants who could be attacked at any time and detained indefinitely without trial. (International Committee of the Red Cross, 2019)

Such example is elucidative of the importance of how words and concepts can be employed to validate and enforce particular perspectives and corresponding courses of actions: in this case, detainees of the war on terror - whether soldiers or civilians, members of Al-Qaeda or not- were not treated as prisoners of war, and their detention/imprisonment existed in legal vacuum outside of the codes of conduct established in the Geneva Conventions and other regulations of International Humanitarian Law.

People tend to apprehend or to dismiss as less important or inexistent from their own knowledge what the words and the rationale of the words they hear include, exclude or neglect on specific topics, issues or groups. Concepts and their meaning contribute to form what Michel Foucault (1980) calls a discursive formation, i.e. a particularly logical way of representing and, thus, legitimating reality and actions upon the latter. When declarations about a topic are made within a specific discourse, the discourse makes it possible to construct the topic in a certain way excluding henceforth other ways of reasoning about the exact same reality, subject, object, topic or event (Hall, 2007).

Just like other spheres of modern knowledge, as well as the realities it explores and systematizes, the sphere of the media has also been subjected to the indolent reason rationale and the subsequent abyssal line it produces. In defining the bulk of what constitutes the media, modern knowledges elected a sole filter technology-, perceived according to the western conception of technology, and 
created derivative concepts which perceive and categorize media realities not for what they are per se, but in relative terms, i.e., for how distant they are from the western technology evolutionary model. Indeed, the western approach to the concept of technology reproduces the "monoculture of linear time" (Santos, 2006) which, based upon the modern discourse of evolution where reason projects a progressively better future, it fallaciously perceives time as a linear evolutionary and universal line towards modernity and allows for the identification of those — societies, people, knowledge(s) - which are behind and the ones which are (most) advanced. As such, a western approach to technology will always privilege media which includes state-of-the-art technology in detriment of all other media.

By commonly overlapping high-tech media with media in terms of category, existing literature conflates both terms as a single concept while all other nontechnological or technologically obsolete media are hierarchized and ranked below the current state-of-the-art technological media and gradually dismissed as traditional, popular, alternative, folk or "peripheral supplements" or "add-ons to technology media" (Ansy-Kyeremeh, 2005: 4). As such, when identifying and thinking on what is the media one can effortlessly fall into what we label as an optical illusion trap, i.e., the notion of the media, despite perceived as a whole, is filled mostly by one of its parts: the high-technology part assumes the neuralgic whole of the mediascape, rendering all other media expressions and channels peripheral, invisible or dismissed as folk, "inconsequential" (Ibidem: 1) or less important. According to Ansy-Kyeremeh (2005: 1):

[i]n the field of communication in particular, and more so in mass communication, indigenous forms and dimensions of communication are often dismissed as "inconsequential", or only casually mentioned in the mainly Eurocentric mainstream research. There are usually descriptive accounts of certain forms of "indigenous communication systems" without any theoretical and in-depth discussion and analysis of how those systems relate to the larger issues of social relations and interaction within the societies concerned.

In fact, the optical illusion that constitutes the modern conception of the media is caused by the indolent reason and the subsequent abyssal line, and, hence, mistakes a tree for the forest, and uses western lenses - inaccurately assumed 
as universal - to perceive and reason and act upon the world, its agents, its features and its dynamics. This is hegemonically repeated and mainstreamed into dominant science and policy initiatives (Foucault, 1995 [1975]; Gramsci, 1971).

Applying the abyssal line metaphor to the mediascape divides it into two sides: on one side of the line are the developed, high-tech, rational, modern and scientific media, whereas other forms of media which do not entail state-ofthe-art technology or that do not necessarily conform with western notions, perspectives, and regulation are instead situated on the other side of the abyssal line and automatically labelled in relative terms to the western, presumed universal and modern mode, as exotic, traditional, indigenous, folk, popular - e.g. the so-called "traditional systems of communication" (Wilson, 1987), "indigenous communication" (Ansu-Kyeremeh, 2005), "cultural forms of communication" (Morrison, 2005)—.

\section{The technology conundrum and the other side of the line: Media beyond technology and high-technology}

This section intends to discuss how the dominant conception of the media draws a mediascape abyssal line by exploring the main filter - i.e., the Modern conception of technology - to make a communication tool be included or excluded from media. Also, this section aims to shed light on other non-technological or nonhigh-technological communication ecologies and communication grammars, exploring how mass communication in the world exceeds the western conception of mass communication.

Within the modern notion of media, modern technology represents the main mediascape abyssal line, i.e., it constitutes the main filter of inclusion or exclusion of what can be labelled and perceived as media, hence, including and excluding which voices (and knowledges) matter and should be heard. 
Nowadays, when the idea of media crosses one's mind, thoughts and notions of technology, airwaves, satellite, automaticity, immediacy, which themselves entail a logic of rationality and scientific background, quickly emerge. This happens due to the fact that the evolution of what is commonly understood as media goes on par with the evolution of the modern western society perception and has, hence, been defined by a modern ${ }^{4}$ and high technologically-driven approach. This approach creates two filters to decide what to be included in the "modern media" or just "media".

The first filter is technology in itself: to be or not to be technologically-based. Technology is here envisaged as the use of knowledge and techniques to optimise processes, and produce goods and/or solve problems. In this sense, media merely based upon orality, with no other tools, such as what happens in some storytelling practices, would fit in the non-technologically-based side of the line. The second filter is based upon a technological spectrum and it divides those media which are made up of high-technology and which, therefore, should be integrated into the media category; and media which, since made by a specific technology which time has rendered obsolete, will no longer be included as such in the media category or, when included, will be labelled as antagonists of modern, rational or technological. The book is a very recent example of this technological obsolescence. Although the creation of the book was a technological revolution, today it is hardly considered a technological product or even media. Indeed, with the outburst of digital communication technology since the end of the last century, computer games, video games, and new online social media started to be included in the media palette, while books started to be dismissed as a mere cultural product -a trend which highlights the "technological Darwinism" in media definition-. Also, the fact that we call "new media"5 to the technological online and on-demand media is elucidative of this "technologically-driven Darwinism", where the technological filter and the meta-narrative of progress prevail in defining the media. However, notwithstanding this trend, there are many other non-technological or non-hightechnological communication grammars which also wide reach.

\footnotetext{
4. Here modern is perceived not as progressive but as deriving from modernity as a social, political, economic and cultural project.

5. New online social media, i.e., communication tools which are specifically defined by offering, at any time, through any electronic device, access on demand to contents created or chosen by individual users in an interactive (creative or reproduced), mobilising and networked logic (Aday, 2010; Bennett, 2003).
} 
The concept and the practices of media in the world exceed the western progressive technological dominant approach and the tradition of orality overcomes, in some cases, the dominance of high-technology. Particularly, in the Global South ${ }^{6}$ the "livros de cordel" throughout Latin American communities, or the street theatres, the forum theatres and the collective meetings in public spaces or village conversational spots across African communities (Ansy-Kyeremeh, 2005; Wilson, 1987) are examples of how the concept of media in the world exceeds the western technologically-progressive dominant approach and how the tradition of orality overcomes, in some of these cases, the dominance of western conceptions of technology.

These media are based upon knowledge, experiences and expressions, embedded with a strong sense of cultural identity, and passed down from generation to generation (Crowder et al., 1998) just like, we argue, the media in western societies. Indeed, these media include "structures that are fully integrated into the interactive holistic social systems of the societies concerned (...) [and] serve to meet the communication, social interaction, information, educational, development and entertainment needs of the people" (Ansy-Kyeremeh, 2005: 2-3). Stating the importance of these media is the fact that they perform a central and not peripheral role within their societies, highlighted by the majority of the communication for development (C4D) projects which target these specific media as key agents to successfully spread a specific intended message in those societies (Crowder et al., 1998; Morrison, 1993).

\section{Illustrative analysis}

As this article argues that the bulk of dominant media studies explicitly and/or implicitly excludes forms of mass communication that go beyond the media in its western liberal form and procedures, we conducted an illustrative analysis of journal articles to capture the most recent trends in media studies research and to understand whether there is a predominant conception of media as digital,

\footnotetext{
6. This article does not argue that non-technological or technologically-obsolete media are more prominent in the Global South than in the Global North. In fact, one could argue there are not many differences in those tools and practices across the globe. Nevertheless, this article does have a focus on the Global South following the literature of the abyssal line and the Epistemologies of the South. Therefore, the reflection put forward will be centred in the Global South.
} 
technological, online media -in opposition to more traditional, offline and nonwestern (indigenous) conceptions- The illustrative analysis was chosen to gather clear examples of the prevailing notions and conceptions, and a specific quantitative and qualitative coding was defined to assemble our illustrative sample. The research agenda and discussion this paper intends to start is still in its nascent stage, thus requiring further empirical work.

\subsection{Sample and inclusion criteria for studies}

In order to define our sample, we have selected the 2018 top five journals indexed to SCOPUS (i.e. Journal of Communication, Applied Linguistics, Political Communication, International Journal of Press/Politics and Communication Theory), selecting first the research articles that were published between 2016 and 2018 and later those which included in the title one of the following four keywords: media, traditional media, indigenous media and social media. We have then excluded those that are not anchored in Media Studies (e.g. neurosciences) or those that focus on specific theoretical reviews of media studies as a discipline that do not entail topics that were relevant for the object of analysis of this paper. The period 2016 to 2018 was chosen to shed light on some of the most recent trends in media studies research. Most articles that fit our four keywords belong to the Journal of Communication and Political Communication; a few were found on the International Journal of Press / Politics, only one on Applied Linguistics, and none was found on Communication Theory. The sample we collected following these criteria amounted to 116 articles.

\subsection{Quantitative analysis coding and findings}

At the quantitative stage, each article was coded for the following categories: year of publication; journal; and country of author's affiliation. Table I displays our findings: 
Table I

Fildings from the 116 articles reviewed

\begin{tabular}{|c|c|c|}
\hline Year & Number of articles $(116)^{7}$ & Percentage \% \\
\hline 2016 & 34 & 29,31 \\
\hline 2017 & 39 & 33,62 \\
\hline 2018 & 43 & 37,06 \\
\hline Journal & Number of articles $(116)^{8}$ & Percentage \% \\
\hline Journal of Communication & 52 & 44,82 \\
\hline Applied Linguistics & 1 & 0,86 \\
\hline Political Communication & 42 & 36,20 \\
\hline $\begin{array}{c}\text { International Journal of Press/ } \\
\text { Politics }\end{array}$ & 20 & 17,24 \\
\hline Communication Theory & 0 & 0 \\
\hline $\begin{array}{l}\text { Countries of author's } \\
\text { affiliation }\end{array}$ & $\begin{array}{l}\text { Affiliations per country } \\
\qquad(142)^{9}\end{array}$ & Percentage $\%$ \\
\hline United States of America & 61 & 42,95 \\
\hline Netherlands & 12 & 8,45 \\
\hline Germany & 11 & 7,74 \\
\hline United Kingdom & 9 & 6,33 \\
\hline Sweden & 7 & 4,92 \\
\hline
\end{tabular}

7. These figures correspond to the total number of articles and their distribution through the selected time span. 8. These figures correspond to the total number of articles and their distribution through the selected Journals. 9. These figures correspond to the total number of countries of author's affiliation. Whenever an article included two or more authors from the same country, that country was counted as one. Whenever an article had several authors from several different countries, each country was counted. 


\begin{tabular}{|c|c|c|}
\hline China & 6 & 4,22 \\
\hline Austria & 5 & 3,52 \\
\hline Belgium & 5 & 3,52 \\
\hline Australia & 4 & 2,81 \\
\hline Chile & 4 & 2,81 \\
\hline Israel & 4 & 2,81 \\
\hline Argentina & 2 & 1,40 \\
\hline Denmark & 2 & 1,40 \\
\hline Norway & 2 & 1,40 \\
\hline Spain & 2 & 1,40 \\
\hline Switzerland & 1 & 1,40 \\
\hline Colombia & 1 & 0,70 \\
\hline Italy & 1 & 0,70 \\
\hline Japan & 1 & 0,70 \\
\hline Mexico & & 0,70 \\
\hline
\end{tabular}

Source: own elaboration

It is worth noting that the top five countries with the most authors amount to $70,39 \%$ of the entire sample. All five countries are located in North America and Europe, which may help in understanding the enunciation (i.e. Global North) bias. 


\subsection{Qualitative analysis review and findings}

Qualitative analysis was put forward by asking key questions that allowed us to understand, first, which parcel of the mediascape analysed literature referred to when speaking of media, and second, to which processes, elements and dynamics are those parcels identified with.

In terms of findings, through qualitatively analysing the 116 articles, seven major trends were perceived:

- "Media" tends to equal "digital": Of the 116 articles reviewed, the vast majority used the concept media to refer to digital/online social media, highlighting the specific platforms (e.g. Facebook, Youtube, Instagram, Tumblr, Snapchat), communication dynamics and processes that these entail and only a few used the term media to refer to mass media (e.g. Winter et al., 2016; Guess et al., 2018, Bennet et al., 2018; Liang, 2018). The reference to "indigenous media" was not found and none of the articles focused on any other media but mass and online media.

- "Traditional media" as "mass media": Of the 116 articles reviewed, 34 explicit references to "traditional media" were found. These referred either to newspapers, television, radio and magazines, which were explicitly or implicitly identified as offline media. Online media and social media were essentially perceived as non-traditional media (or "new media", as opposed to old media). Traditional media were mentioned generally to: identify offline media outlets and set them apart from online and social media; be described as increasingly losing popularity and users; be described as being less cost-effective than online media. A few articles also highlighted the different message dissemination processes of traditional mass media (one emitter and multiple receivers) and the latter's enhanced data-extraction capacity (e.g. Turow \& Couldry, 2018) as compared to traditional media outlets.

- "Social media" as "digital media": Of the 116 articles reviewed, 48 explicitly referred to "social media". Although not defining the term explicitly, authors used it as implicitly referring to online and on-demand communications channels and platforms whose content is mainly user-generated. i.e., social networking 
sites (SNS). State-of-the-art technology and the digital realm are key elements underpinning the definition. Specifically, when reflecting upon or studying "social media", selected authors usually referred to concrete platforms, namely: Facebook, Twitter, Snapchat, Instagram, Tumblr, Google+, Youtube, Reddit, etc. These online platforms were often portrayed as realms that provide increased opportunities for political engagement and foster less asymmetrical power relationships in societies (e.g. Penney, 2016; Strömbäck et al., 2018).

- Prevalence of state-of-the-art technology in defining media: When mentioning mass media or hybrid media systems, there is an explicit or implicit subtext which evokes the gradative replacement of the so-called "traditional media" by "new/online/digital media" (e.g. Aruguete \& Calvo, 2018; Bennet et al., 2018). That is particularly evident in Mangold and Bachl (2019: 2) when they argue that "the majority of Germans have not (yet) abandoned traditional news outlets, but the coexistence and co-integration of traditional and new media use predominate". According to Turow and Couldry (2018: 415): "New advertising and data-processing developments mean that while the term media may continue to attach to the distribution of narratives, researchers must now conceive it as the convergence of message-circulation technologies with data-extraction-and-analysis technologies that are linked to everyday objects increasingly typical of our new mobile personalization era". Also, Aruguete and Calvo (2018: 482) state that different gaps between the production and consumption functions of information in mass media will progressively render its products to "go unsold or unseen"10.

- Liberal as tendentially universal: References to the liberal mediascape and its consumerist, modern and highly technological essence lacking the specific ideological context in which they are embedded are pervasive in reviewed articles. Most of the times this assertion is made due to the specific liberal case studies that are chosen. Exceptions to this trend are, for example, Moehler, Devra and Conroy-Krutz (2016: 414) who pose the question "How does media exposure affect political engagement in settings that have recently undergone

10. Arguete and Calvo (2018: 3) also state that "This is also true in social media, where some posts are widely read while others fail to attract the public's attention. In social media, however, production costs are lower and consumption leads to propagation." 
media liberalization?" and, when reflecting on Ghana mediascape, contextualise the case study as a society which has undergone a "media liberalization" process (Ibid: 415).

- Little acknowledgement of media ecologies: Usually focusing on a single case study and a single media, the majority of the reviewed articles assume that the specific media which they analysed is universal and seldom recognise the existence of media ecologies. Exceptions to this trend can be found in Bennet et al. (2018) and Kim et al. (2018) who explicitly make use of the words "ecology" or "ecologies" giving insight to the wider media palette that the mediascape entails. Whereas Bennet et al. (2018) use the terms "contemporary media ecologies" and "multimedia ecologies" and "complex media ecologies" when highlighting the interplay between "social and legacy media", and respective framing and gatekeeping processes, with a particular focus on the digital realm; Kim et al. (2018: 515) assert that media ecology along with the technological features and the possibilities of digital media contribute, among other factors, to "the prevalence of anonymous groups' divisive issue campaigns on digital media", narrowing down the prevalent mediascape to the digital realm.

\section{Discussion}

The definition of media used by the articles contained in our sample shows that there is a technological and modernity-driven spectrum that is fundamental in defining what is and what progressively stops being labelled, and hence considered, media. This understanding of the media fails to include forms of mass communication that go beyond the media in its western liberal form and, consequently, exclude subaltern voices, knowledges and messages. 
Although categorisation might be theoretical and analytically useful, it is important to understand the enunciation locus that allow for that categorisation and the political and societal implications of that categorisation (Horkheimer, 1975; Cox, 1981; Grosfoguel, 2011) as well as the fact that reality often exceeds in complexity what analytical frameworks can systemathise.

As Simone Natale (2016) showed in his article "There Are No Old Media", media are constantly changing and evolving, and thus a binary conception of media tends to miss a larger picture. The way we describe media tends to be more of a relational notion that informs more about the author(s) relation to media than a characteristic of media in and of itself. What most authors consider traditional media can also be (and, in fact, many already are) digital media. In the same vein, it is not hard to imagine that what we used to call new online social media a decade ago and now simply call social media will one day in the future be considered traditional media.

Individual bias aside, there is also the need to consider cultural and hegemonic bias. As Shome (2016: 260) stated, "media studies needs to engage postcolonial frameworks so as to be able to address and challenge the North Atlantic centered temporalities that have been assumed in much of media scholarship". Other scholars (Kumar, 2014; Kumar \& Parameswaran, 2018;) also pointed that, if devoid of a postcolonial approach, media and communication studies can present an ahistorical vision of progress, development and globalization that shape and strengthen a western perspective of media history as universal. A media and communications studies that encompasses postcolonial theory not only enables media and communication scholars to clarify "the fluctuating social hierarchies that continue to structure global media imaginaries" (Kumar \& Parameswaran, 2018: 348), but also develop a more refined knowledge on how "media and communication phenomena are enmeshed in global permutations of dominance" (Kumar \& Parameswaran, 2018: 348).

An example of how the scholarship on digital media can benefit from a postcolonial approach is by challenging the opacity of technology as a means of domination embedded in the economic structure of global capitalism and understand it as a cultural, political and economic ethos (Kumar \& Parameswaran, 2018). In 
the article "Media as Data Extraction: Towards a New Map of a Transformed Communications Field", Turow and Couldry (2018: 415) also implicitly denote the connection between a socio-political conception of media and its economic paradigm, when stating:

The communications field must challenge traditional understandings of media in the face of a transformation in the dynamics of capitalism that prioritizes the generation of value from data based on continuous surveillance. New advertising and data-processing developments mean that while the term media may continue to attach to the distribution of narratives, researchers must now conceive it as the convergence of message-circulation technologies with data-extractionand-analysis technologies that are linked to everyday objects increasingly typical of our new mobile personalization era. In fact, nothing less than a radical revision of the boundaries of the communications field is required to adequately address the fundamentally altered social and economic order emerging from this ferment in the field of everyday life itself.

\section{Conclusions: Towards an equal recognition of "communication grammars" and "communication ecologies"}

In terms of communication, the whole mediascape is crucial for the understanding of the importance of voice in the correlation of power and, hence, for the construction and transformation of societies. Voice and subsequent consequences of the use of voice are the key aspects of the central role mediascape performs in every society. By tipping the balance in validating and projecting some media and, consequently, some voices and respective knowledges and accounts, in detriment of others' neglect or exclusion, the dominant conception of media affects and has consequences in power relations and, subsequently, in society's inclusion, maintenance and transformation - both at a local, national and international level- . This means that, by drawing an exclusionary abyssal line, the dominant conception of media recognises "voice as a process" - i.e., people can give an account of themselves in different ways and spheres - but by narrowing it down to the dominant conception of media, it denies and/or undermines "voice as a value". The abyssal line that is drawn in the mediascape is problematic because it 
ultimately excludes voices and, subsequently, knowledges, accounts, experiences and agendas, from the dominant public debate and, therefore, as all knowledges are incomplete (Santos, 2007), also renders the West more ignorant.

The consequences of a mediascape abyssal line are two-fold: first and foremost, it produces an analytical and epistemological biased framework. By conflating the concept of media with the western modern conception of media, it excludes and renders invisible certain parts of reality and, in turn, renders the visible side of the line ignorant of those who are on the other end of the abyssal line. The second consequence is correlated with the first one: this analytical and epistemological bias is accompanied by a politically hegemonic bias, i.e.: by excluding or rendering invisible knowledges, voices or realities in such conceptions those same subjects are also politically excluded and rendered invisible, thus affecting the construction and transformation of societies and preventing a horizontal dialogue among different knowledges and different grammars of perceiving and organising societies. As Tacchi states, this is an issue of "communicative justice" (Tacchi, 2012), "a question not simply of access to production, but also the quality of relationships between speakers and listeners mediated by technologies and institutions" (Tacchi, 2012: 232).

By overcoming the abyssal thinking, distinct grammars of communication and ecologies of communication that constitute the mediascape - as well as attached knowledges, experiences and accounts of oneself- can arise. As horizontal communication between different ecologies of communication and ecologies of knowledge emerge, people's general capacities to give an account of themselves with subsequent equal political consequences may materialize. Acknowledging alternative forms of knowledge and media practices as being on the same level requires us to be "prepared to accept and respect alternative knowledge and knowledges practices, which may be contradictory to dominant knowledge practices and beliefs" (Tacchi, 2012: 234). 


\section{Bibliography}

- ADAY, S. et al. (2010). New media and contentious politics. Retrieved from USIP's website. Available online at http://www.usip.org/sites/default/files/pw65. pdf.

- ANDERSON, J. (1995). Translator's Introduction. In A. HONNETH (1995 [1949]) The Struggle for Recognition: The Moral Grammar of Social Conflicts. Cambridge, Massachusetts: MIT Press.

- ANSU-KYEREMEH, K. (2005). Indigenous Communication in Africa: Concept, Applications and Prospects. Accra: Ghana University Press.

- APPADURAI, A. (2004). The Capacity to Aspire: Culture and the terms of recognition. In V. RAO \& M. WALTON (eds.) Culture and Public Action (pp. 5984). Stanford CA: Stanford University Press.

- ARAÚJO, S. \& SANTOS, S. J. (2017). Media e as Epistemologias do Sul, Janus Anuário 2017. OBSERVARE, Lisboa: Universidade Autónoma de Lisboa.

- ARUGUETE, N. \& CALVO, E. (2018). Time to \#Protest: Selective Exposure, Cascading Activation, and Framing in Social Media. Journal of Communication, 68(3), 480-502. doi: https://doi.org/10.1093/joc/jqy007

- BENNETT, W. L. (2003). News: The Politics of Illusion. New York: Longman.

- BENNETT, W. L., SEGERBERG, A. \& YANG, Y. (2018). The Strength of Peripheral Networks: Negotiating Attention and Meaning in Complex Media Ecologies. Journal of Communication, 68(4), 659-684. doi: https://doi.org/10.1093/joc/ jqy032

- BRIGGS, A. \& BURKE, P. (2009). A Social History of the Media: From Gutenberg to the Internet. Cambridge: Polity Press.

- COHEN, M. \& GLOVER, J. (2014). Colonial Mediascapes. Lincoln and London: University of Nebraska Press. 
- CROWDER, L. V., LINDLEY, W., TRUELOVE, W., ILBOUDO, J. P. \& DEL CASTELLO, R. (1998). Knowledge and information for food security in Africa: from traditional media to the Internet, FAO. Available online at http://www.fao.org/docrep/ w9290e/w9290e00.htm

- COULDRY, N. (2010). Why voice matters. Culture and politics after neoliberalism. London: Sage Publications.

- COX, R. (1981). Social Forces, States and World Order, Millenium. Journal of International Studies, 10(2), 126-155.

- FOUCAUlT, M. (1995[1975]). Discipline and Punish: The birth of the prison [Translated from the French by Alan Sheridan]. New York: Second Vintage Books Edition.

- FOUCAULT, M. (1980). Power/Knowledge. Brighton, UK: Harvester.

- GRAMSCI, A. (1971). Selections from the Prison Notebooks of Antonio Gramsci. New York: International Publishers.

- GROSFOGUEL, R. (2011). Decolonizing Post-Colonial Studies and Paradigms of Political Economy: Transmodernity, Decolonial Thinking, and Global Coloniality. Transmodernity: Journal of Peripheral Cultural Production of the Luso-Hispanic World, 1(1).

- GUESS, A., MUNGER, K., NAGLER, J. \& TUCKER, J. (2018). How Accurate Are Survey Responses on Social Media and Politics? Political Communication, 36(2): 241-258. doi: 10.1080/10584609.2018.1504840

- HALL, S. (2007).The West and the Rest - Discourse and Power. In S. HALL et al. (2007) Modernity-An Introduction to Modern Societies (pp. 184-227). The Open University.

- HORKHEIMER, M. (1975). Critical Theory: Selected Essays. New York: Continuum International Publishing Group.

- INTERNATIONAL COMMITTEE OF THE RED CROSS. (2019). Glossary: War on Terror. Retrieved online at https://casebook.icrc.org/glossary/war-terror 
- KIM, Y. M., HSU, J., NEIMAN, D., KOU, C., BANKSTON, L., KIM, S. Y., HEINRICH, R., BARAGWANATH, R. \& RASKUTTI, G. (2018). The Stealth Media? Groups and Targets behind Divisive Issue Campaigns on Facebook. Political Communication, 35(4), 515-541. doi: 10.1080/10584609.2018.1476425

- KUMAR, S. (2014). Media, communication, and postcolonial theory. In M. FACKLER \& S. S. FORTNER (Eds.), The handbook of media and mass communication theory (pp. 380-399). Oxford: Wiley.

- KUMAR, S. \& PARAMESWARAN, R. (2018). Charting an Itinerary for Postcolonial Communication and Media Studies. Journal of Communication, 68, 347-358.

- LIANG, H. (2018). Broadcast Versus Viral Spreading: The Structure of Diffusion Cascades and Selective Sharing on Social Media. Journal of Communication, 68(3), 525-546. doi: https://doi.org/10.1093/joc/jqy006

- MANGOLD, F. \& BACHL, M. (2018). New News Media, New Opinion Leaders? How Political Opinion Leaders Navigate the Modern High-choice Media Environment. Journal of Communication, 68(5), 896-919. doi: https://doi. org/10.1093/joc/jqy033

- MOEHLER, D. \& CONROY-KRUTZ, J. (2016). Partisan Media and Engagement: A Field Experiment in a Newly Liberalized System. Political Communication, 33(3), 1-19.

- MORRISON, J. F. (1993). Communicating healthcare through forum theater: egalitarian information exchange in Burkina Faso. International Communication Gazette, 52(2), 109-121.

- PEnNeY, J. (2017). Social Media and Citizen Participation in "Official" and "Unofficial" Electoral Promotion: A Structural Analysis of the 2016 Bernie Sanders Digital Campaign. Journal of Communication, 67(3), 402-423. doi:10.1111/jcom.12300

- SANTOS, B. S. (2014). Epistemologies of the South. Boulder: Paradigm.

- SANTOS, B. S. (2007). Para além do Pensamento Abissal: Das linhas globais a uma ecologia de saberes. Revista Crítica de Ciências Sociais, 78, 3-46. 
- SHOME, R. (2016). When postcolonial studies meets media studies. Critical Studies in Media Communication, 33(3), 245-263.

- STRÖMBÄCK, J., FALASCA, K. \& KRUIKEMEIER, S. (2018). The Mix of Media Use Matters: Investigating the Effects of Individual News Repertoires on Offline and Online Political Participation. Political Communication, 35(3), 413-432. doi: 10.1080/10584609.2017.1385549

- TACCHI, J. A. (2011). Open content creation: The issues of voice and the challenges of listening. New Media \& Society, 14(2), 652-658.

- TACCHI, J. A. (2012). Digital Engagement: Voice and Participation in Development. In H.A. HORST \& D. MILLER (Eds.). Digital Anthropology (pp. 225-242). London: Berg.

- TUROW, J. \& COULDRY, N. (2018). Media as Data Extraction: Towards a New Map of a Transformed Communications Field. Journal of Communication, 68(2), 415-423. doi: https://doi.org/10.1093/joc/jqx011

- WILSON, D. (1987). Traditional Systems of Communication in Modern African Development An Analytical Viewpoint. Africa Media Review, 1(2), 87-104.

- WINTER, S., METZGER, M. J. \& FLANAGIN, A. J. (2016). Selective Use of News Cues: A Multiple-Motive Perspective on Information Selection in Social Media Environments. Journal of Communication, 66(4), 669-693. doi:10.1111/ jcom.12241 


\section{Biographies}

\section{Alexandre de Sousa Carvalho}

University of Coimbra (Portugal)

ORCID: 0000-0002-9096-393X

asousacarvalho@fe.uc.pt

Guest Assistant Lecturer at the Faculty of Economics of the University of Coimbra since February 2017, where he has been lecturing at undergraduate and graduate programmes in International Relations, Development, Peace and Security Studies. He is a PhD Candidate in Political Science at ISCTE-IUL in Lisbon and holds a Master's degree in African Peace and Conflict Studies from the University of Bradford, UK. His areas of expertise lie in peace and security studies; power-sharing studies; foreign policy; political science and populism. Alexandre is a researcher at DeCode/M, where he facilitates the thematic area "Populism and Extreme Masculinities", and actively participates in the core study, "Me Too" and "Fatherhood, Household Roles and Caregiving" and also contributes to the communications and outreach strategy.

\section{Sofia José Santos}

University of Coimbra (Portugal)

ORCID: 0000-0001-9300-7452

sjs@ces.uc.pt

Assistant Professor in International Relations at the Faculty of Economics, University of Coimbra, and a Researcher at the Center for Social Studies, where she coordinates the DeCodeM project as a Principal Investigator. Since 2008 she has developed research on media and international relations; media and securitization processes; internet and technopolitics; and media and masculinities. Within CES, she is also coordinator for Promundo-Portugal's Media and Masculinities programming area, and co-editor of Alice News. She holds a PhD in International Politics and Conflict Resolution by the Faculty of Economics of the University of Coim- 
bra and a Diploma in Advanced Studies in Communication Sciences from ISCTE-IUL. Her current research interests focus on media representations and securitization; media and foreign policy; media, masculinities and violence prevention; digital rights and contentious politics; and critical Internet studies.

\section{Carlota Houart}

University of Coimbra (Portugal)

ORCID: 0000-0002-7428-6852

carlotahouart@ces.uc.pt

International Relations graduate by the Faculty of Economics of the University of Coimbra, and a Master's student in International RelationsPeace, Security and Development Studies at the same University. She is a junior researcher of the Centre for Social Studies of the University of Coimbra (CES-UC) as member of NHUMEP and member of the team of the DeCodeM Project. Her research interests include IR, peace and conflict studies, gender studies focusing on masculinities, media studies, ecofeminism and climate change. 